\title{
DEVELOPMENT AID IN NORTHEAST ASIA
}

\author{
Sahiya Lhagva \\ An Oven'iew of Development Aid in Northeast Asia
}

It is well known that Northeast Asia covers different economies which vary considerably in terms of economic development and political orientation. According to some estimates, per capita GDP varies from US \$ 306 in Jilin province of China to US \$25,230 in Japan. Most of the continental part of the region has much untapped mineral, forest, human and land resources but badly needs capital, especially physical capital, and modern technology for its sustainable development. Japan and South Korea, on the other hand, have both ample amounts of capital and modern technology but need natural resources and labor. There seems to be enough potential for cooperation within Northeast Asia, yet so far regional economic cooperation has been low. Partly due to political barriers and incompatible ideologies. While Northeast Asia has 17.8\% of the world's population, its regional trade is only $1.92 \%$ of world trade.

Development aid within the region presents the same picture. On the one hand, Japan is the second largest aid donor country and China is one of the largest aid recipients in the world, but on the other hand, development aid within North-east Asia is a mere trickle. For instance, in 1990, Northeast Asia and all of China accounted for only $12 \%$ of Japanese development aid while Southeast Asia accounted for $34.3 \%$.

Undoubtedly political and economic reforms in Russia and Mongolia, and China's open-door policy will offer new opportunities for regional integration. Unfortunately, whereas a successful integration process requires more or less equal levels of development in participating economies. Northeast Asia includes both developing and developed economies. Thus there is a need for assisting the former and enabling the latter to distribute this assistance. In short, development aid within the region is a matter of some importance, especially since difficulties have arisen in Russia and Mongolia during the transition from planned to market economies.

It is commonly assumed that the Russian Far East, Mongolia, Northeast China, and North Korea would be the primary aid recipients in the region. This is generally true, but one should bear in mind that there are wide variations among 
these economies. Both Russia and China have enormous economic potential, but Russia is an above-average income country while China is the largest developing country in the world. At the same time, China's economy is outpacing any other in the world, while Russia's has declined during the last three years because of its current crisis caused by the social transformation from communism to democracy. Besides, the Russian Far East is less developed than the rest of Russia, with an underdeveloped infrastructure, structural imbalances, and a low population density', while Northeast China ranks as a middle-income territory with basic industries, a relatively developed infrastructure, and a high population density.

The situation in Mongolia is quite different. As a developing country, Mongolia's per capita GDP is higher than China's, but its economic potential is smaller than either Northeast China's or the Russian Far East's. Mongolia is also extremely dependent on external resources due to its heavily imbalanced import incentive structure. Along with other factors such as its landlocked location, narrow market and underdeveloped infrastructure, it makes it impossible to rebuild Mongolia's economy with only domestic resources.

Recognizing the importance of external resources for their economic development, all three countries pursue policies to attract direct foreign investment. Russia and Mongolia, however, have not had much success in implementing this policy, mostly due to political instability in Russia and an inadequate economic environment in Mongolia. North Korea's policy of Juice, or self-reliance, has created a widely diversified economy, which is not highly competitive in international markets due to its backward technology in a number of industries. Therefore, in order to participate in regional economic integration, North Korea would need to make some structural adjustments, and it is not certain that the country has enough resources for that. If, however, Korea become united again, development aid for the northern part would then come largely from the southern part of the country.

All this shows how aid requirements differ from country to country as well as how important development aid is for this region's economies. Russia and China would need large amounts of aid but they are also in a better position than others to implement the necessary structural changes. For North Korea it is largely a matter of political decisions. Mongolia has the greatest need for development aid because of its limited capital and technological resources. On the supply side. Japan and South Korea are expected to be the main donor countries in the region, but there is also some possibility of aid by Russia and China to Mongolia, to each other and to others. 
In this regard, it should be noted that until recently Northeast Asia was the recipient of two different kinds of development aid. The former Soviet Union was the main donor for Mongolia and North Korea for a long time. It gave aid primarily not for economic but ideological and political objectives. This resulted in economies heavily dependent on the Soviet Union and incapable of developing their own economics.

The second kind of aid went from Japan to South Korea and China. Japan's total development aid to South Korea for 1986-1990 amounted to US \$ 1, 481, 160,000 and to China US $\$ 4,809,690,000$. While there were no disbursements to the former Soviet Union, Russia or North Korea, Mongolia has received US\$ $4,720,000$ since relations between the two countries have been regularized. Japanese aid has been based on humanitarian considerations and recognition of increasing interdependence. It has also supported self-help efforts in recipient countries to accelerate their economic and social development. Still, Japan's motives are not devoid of political and economic self-interests. Japan's aid to South Korea decreased during the 1980 and then stopped altogether in 1990, as Japan shifted its aid funds to China and Mongolia.

South Korea's activities as a donor of development aid began in the midsixties, but its development aid has been distributed mostly outside this region and has covered many countries. For example, during the period from 1977 to 1990 , US \$ 91 million in grant aid was allocated to more than one hundred countries around the world, of which $41 \%$ went to Africa and $29.3 \%$ to Latin America. In 1990 alone, US \$ 11 million of grant aid was distributed among ninety-four countries, of which forty-five countries received each US $\$ 100,000$ or less.

These and other facts make one think that so far South Korea's development aid has not been guided by any clearly defined philosophy, except to use aid merely as a means of obtaining support from Third World countries in its diplomatic offensive against North Korea. However, it has been South Korea's view that its prosperity rests largely on stable economies in developing countries. It is also possible that South Korea may soon change its aid philosophy and focus on fewer countries.

Besides the two main types of development aid, there were smaller amounts of aid from China to Mongolia and North Korea. They had mostly humanitarian motives and therefore had lesser consequences for the region's economic state, but with China's economy continuing its rapid growth, Chinise aid can be expected to gain in importance in the near future. This quick overview of current development aid within Northeast Asia suggests that it might play an important 
role in regional integration. This could be accomplished by supporting Russia and Mongolia in their efforts to overcome the current economic crisis and stabilize their economies, and by strengthening the economies of the Russian Far East, Northeast China, Mongolia, and North Korea. The most effective role that development aid could play in this region is that of a pump primer. Specifically, if aid were concentrated in the building of infrastructures, it would help attract private businesses, especially direct foreign investment. Nowhere is this more obvious than in the Russian Far East and in Mongolia. Reaching the mineral and forest resources hidden away in the vast reaches of the Russian Far East and Mongolia requires a much greater density than 3.4 and $2.5 \mathrm{~km} / 1000 \mathrm{sq}$. km of roads and 1.3 and $1.2 \mathrm{~km} / \mathrm{sq}$. km of railroads that are currently available in these regions.

Developing infrastructures in the Russian Far East and Mongolia is also important for yet another reason, the creation of an Eurasian land bridge. The basic elemenls of inlermodal transport systems already exist, linking the eastern seaports of Russia and China with Europe through the Trans-Mongolian, TransManchurian, and Trans-Siberian railways, but so far they have had little impact on the economies of Northeast Asia. Strengthening the infrastructures would not only increase the trade volume on the Eurasian land bridge, but would also help both the individual economies and regional economic integration.

\section{The Role of External A id to Mongolia}

Mongolia's economy is quite special. Due to its lanbdlocked location, altitude and climate, it was based for thousands of years almost exclusively on nomadic herding. Not until the early 1960s did industrialization result in basic changes in the economy. It diversified, creating new sectors and sharply increased Mongolia's economic potential. In 1989 the national income was 4.05 times and industrial output 12.75 times that of 1960 For Mongolia which did not have enough capital resources to implement such broad-gauged industrialization on its own. development aid played a crucial role. Share of domestic savings in total investment expenditure has not exceeded $45 \%$ since the $1970 \mathrm{~s}$. At the same time, until recently capital flows to Mongolia were limited to project and trade loans and grants from the former Soviet Union and other CMEA countries.

The greatest share of development aid to Mongolia was taken by project loans which divided into two groups, turnkey projects and technical assistance. These two types of loans differed in that turnkey projects covered all costs and 
technical assistance projects only sonic of the cost. Trade loans were not projectrelated resource flows but set aside for financing Mongolian imports from the Soviet Union. Project loans usually carried an interest rate of $1.5-2.0 \%$ per annum and a 15-year maturity, but trade loans had shorter maturities. Grants provided not only for training, specialists and the like, but also for the development of a social infrastructure, such as housing, hospitals and schools. The share of grants in total aid from the Soviet Union to Mongolia during 1976-1990 equaled $7.0 \%$.

However, all types of aid provided by the Soviet Union and CMEA countries were tied to imports from the donor countries and granted in transferable rubles Newly built sectors were supplied mostly with equipment and technology made by those nations and, consequently, needed spare parts from there as well. In 1989 over 80\% of Mongolia's imports were from the Soviet Union, about 95\% from CMEA countries, and their share in total foreign trade turnover equaled the same percentage.

The key role in carrying out this industrial development policy was played by soviet economic advisors and specialists. Mongolia's role in this was small not only because of political reasons but also because of its small scientific and human resources. Industrialization was based on Mongolia's main resources, animal products and minerals. By the beginning of the 1960s there were already more than 160 industrial enterprises, mostly primary processing of animal raw materials. During the next thirty years Mongolia attempted to process its own animal products and minerals, and by the mid-1980s Mongolia was able to process $70-95 \%$ of skins. $50 \%$ of wool, and $50 \%$ of meat.

The mining sector was rapidly expanded by the creation of several joint ventures with CMEA countries. The opening in the last 1970s of the copper plant in Erdenet, a joint venture with the USSR, brought about a major change in Mongolia's economic structure. Copper ore became the most important industrial export, comprising about $40 \%$ of Mongolia's total exports. Also, some import-substituting industries, such as construction materials, wood processing, clothing, glass and food processing were built. A byproduct, of rapid industrial expansion was a sharply increased demand for power and physical infrastructure, and several coal mines and coal-fired power stations were set up As a result, the share of investment in export-oriented subsections of the industry was relatively low, with an estimated $35-40 \%$ of project loans being allocated to these sectors.

Thus the model of industrialization which was implemented in Mongolia resulted in creating a high-capital and import-intensive structure with centrally 
planned management. Any growth of this kind of economy required an increasing volume of external subsidies and in that way, expanded import dependency on donor countries. Clearly under these circumstances, the end of Soviet aid and the collapse of the CMEA system have been a major shock for Mongolia and could lead to the economic breakup of the country. The need for external assistance was obvious, and the international community rendered emergency aid.

At donor consultation meetings held in September and October 1991 international organizations and donor countries agreed to provide about US \$220 million as emergency aid for 1991-92. In May 1992, at the second assistance group meeting held in Tokyo, about US \$ 340 million of aid was indicated and or confirmed. However, by the end of 1993 about $49 \%$ of agreed assistance had actually been used. Table 1 presents a summary of external aid commitments and disbursements.

Table 1

\section{Total Commitments and Disbursements of External Aid to Mongolia in 1991-94}

$\begin{array}{rll}\text { 1991/92 } & \text { Commitment } & \text { Disbursement } \\ \text { of which grants } & 241.96 & 6.83 \\ \text { 1992/199.1 } & 79.16 & 6.83 \\ \text { of which grants } & 464.25 & 234.46 \\ \text { 1993/1994 } & 179.35 & 91.52 \\ \text { of which grants } & 39.36 & 190.02 \\ \text { Total. 1991-1994 } & 882.57 & 85.93 \\ \text { of which grants } & 297.88 & 431.41 \\ & & 184.37\end{array}$

(US S million)

When Mongolia first appealed to Western countries for assistance, it had already started its economic and political reforms. As the reforms progressed, the very deep roots of the current economic crisis were revealed and the need for long-term assistance became obvious. There is a broad consensus among donors that help for the rehabilitation and expansion of the economic infrastructure will be increasingly important for Mongolia in the near future. Consequently, the composition of aid has been changing, with emergency-type assistance, like food, medicines and other commodities, declining and structural adjustment increasing. The latter accounted for 3\% in $1991,14.6 \%$ in 1992 . And $34.3 \%$ of total aid received by Mongolia. 
Japan is the largest donor country since Soviet aid was terminated. As Table 2 shows, its share in total aid to Mongolia during J 991-93 equaled 26.5\% while Mongolia received about one-third of all its aid from Northeast Asian countries.

Table 2.

\section{Geographic Composition of External Aid to Mongolia}

$\begin{array}{ll}\text { Regon } & \text { Share in total of disbursed aid, \% } \\ \text { Asia } & 34.8 \\ \quad \text { NEA countries } & 33.4 \\ \text { Japan } & 26.5 \\ \text { China } & 1.0 \\ \text { Russia } & \text { S.2 } \\ \quad \text { Republic of Korea } & 0.7 \\ \text { Europe* } & 16.1 \\ \quad \text { Germany } & 10.0 \\ \text { USA } & 14.4 \\ \text { Australia and New Zealand } & 0.1 \\ \text { International organizations } & 34.5\end{array}$

Thus Mongolia, being the least developed economy in the region, needs assistance not only to support its transition to a market economy but also to create a basis for future sustainable economic growth. This requires, besides external resources, a development strategy which sets the priorities of investment and utilizes external aid in the most efficacious way. Unfortunately, it is far from clear that such a development strategy is being formulated. Currently, energy. Transport and communications are considered the key sectors requiring donor support. However, their development plans should be determined by a development strategy that encompasses the entire economy and identifies possible areas of specialization in this region and in the world. 